Indo Global Journal of Pharmaceutical Sciences, 2019; 9(2): 63-68

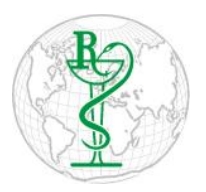

INDO GLOBAL JOURNAL OF

PHARMACEUTICAL SCIENCES

ISSN 2249- 1023

\title{
Development of Molecular Condom by Using Anti-Fertility Phytochemical
}

\author{
Asha Kadam ${ }^{1 *}$, Balasaheb Gaykar ${ }^{2}$ \\ ${ }^{l}$ Department of Botany, New Arts, Commerce \& Science College, Ahmednagar, Dist. Ahmednagar (M.S.) \\ ${ }^{2}$ Department of Botany, Ahmednagar College, Ahmednagar (M. S.)
}

Address for Correspondence: Asha Kadam, ashakadam16@gmail.com

Received:

01.02.2019

Accepted:

29.06.2019

\section{Keywords}

Molecular

condom,

Pregnane,

Ethynyl estradiol, Diosgenin, DepoProvera.

\begin{abstract}
There are some herbal contraceptives that have the property to avoid the embryo implantation. Trigonella foenum-graecum L. is used in folk medicine for prevention of pregnancy. Pregnane- progesterone is one of the important steroid found in Trigonella has direct connection with contraceptive activity.Pregnane is a $\mathrm{C}_{21}$ steroid and indirectly, a parent of progesterone. The present study showed the presence of [5 Beta]-Pregnane-3, 20, beta-diol, [4 alpha] 8-alpha-[4-methyl-3-oxa] oxa-4ozabutane-1, 4 diyl-diacetate. This pregnane was found first time in this plant. Pregnane progestin contraception is effective and well tolerated, thus providing an excellent Molecular contraceptive alternative to the currently used methods. Pregnane can be isolated from Trigonella foenum-graecum L. for the preparation of Depo-Provera as a contraceptive measure. Ethinyl-estradiol is an estrogen that is active when taken by mouth and is used in almost all formulation of combined birth control pills, and is nearly the exclusive estrogen used for this purpose. Estrogen contributes to ovulation suppression. The ethinyl estradiol has high estrogenic potency when administered orally, and is often used as the estrogenic component in oral contraceptive. Diosgenin in is the most widely used precursor in the preparation of many steroid drugs, sex hormones and oral contraceptives pills. In the present study the concentration of Diosgenin was estimated in the seeds of Trigonella foenum-graecum $\mathrm{L}$. The above mentioned anti fertility phytochemical can be used as to develop molecular condoms. (c) 2019 iGlobal Research and Publishing Foundation. All rights reserved.
\end{abstract}

Cite this article as: Kadam, A.; Gaykar, B. Development of molecular condom by using anti-fertility phytochemical. Indo Global J. Pharm. Sci., 2019; 9(2): 63-68. DOI: http://doi.org/10.35652/IGJPS.2019.9202

\section{INTRODUCTION}

Phytochemical found in plants are progressively gaining popularity over conventional artificial drugs to prevent or treat chronic diseases. During the recent past the interest has developed again in study and use of traditional medicinal plants. More people are realizing that the natural is better. Most of the traditional plant based remedies are back in use and find increasing as therapeutic agent, raw material for new synthetic compound and a major molecule for the discovery of molecule. The use of herbal crude drugs, extracts and their remedies have significantly increased throughout the world and the green revolution in terms of herbal medicine has now achieved astonishing popularity. Natural drugs are being used as antimicrobial [1, 2, 3], antifungal [4], antiviral and antifertility [5].

Since many years workers are trying to find out innovative plant based drugs containing medicinally valuable photochemical. These are alkaloids, glycosides, phenolic compounds, steroids, and terpenoid derivatives. The 


\section{Indo Global Journal of Pharmaceutical Sciences, 2019; 9(2): 63-68}

assessment of the drugs is based on phytochemical and pharmacological approaches proceed to the drug discovery referred as natural product screening [6]. The plant parts contain active components [7]. People have been trying to reduce and treat diseases with different plant extracts and formulations [8]. It was reported that more than 119 phytochemical were isolated and identified from higher plants that were being used worldwide as drugs [9].However, the phytochemical composition of the aqueous and petroleum ether extracts of Trigonella foenum-graecum L. and Moringa oleifera Lam. used for medicinal purposes has not been sufficiently studied which may be further evaluated and used for the development of molecular condom. The specific compounds or molecules have not been precisely defined at certain level.

Hence, it becomes essential to evaluate the anti-fertility phytochemical of pharmaceutical importance in relation to development of molecular condom. The phytochemical study was carried out from Trigonella foenum-graecum L. and Moringa oleifera Lam. The presence of active compounds was further correlated with contraceptive activity and evaluation of authenticity of plants.

\section{MATERIALS \& METHODS}

\section{Collection of plant material}

On the basis of literature and survey of trible people [10] following plants were selected for the scientific study of spermicidal activity. The selected plants were Trigonalla foenum-graecum L. (Fabaceae) andMoringa oleifera Lam. (Moringaceae). Seed samples were collected from various areas of Ahmednagar District, India in their natural habitat. They were identified from Botanical Survey of India, Western Circle Pune. The voucher specimens were deposited in the Herbarium, BSI Pune as well as in Herbarium of Department of Botany, New Arts, Commerce and Science College, Ahmednagar.

\section{Extraction of the plant materials}

The seed were air dried at room temperature followed by pulverization to powder form using mortar and pestle. The powdered seeds were subjected to aqueous extraction as well as extraction of active components from seed powder was performed with petroleum ether by using Soxhelet. Polar and non-polar solvent were taken into consideration for extraction. The residues were collected and preserved at $4^{\circ} \mathrm{C}$ for further experiment. The non-polar Petroleum ether was used which being more effective than methanol extracts [11], so the extracts were made in this non polar solvent.

\section{Gas Chromatography-Mass Spectrometry Analysis}

The GC-MS analysis was carried out using a Hewlett packed gas chromatography (model 6890series) equipped with a flame ionization detector and Hewlett Packard 7633 series indicator, MS transfer line temperature of $250{ }^{\circ} \mathrm{C}$. The GC was equipped with a fused silica capillary column HP -5MS (30x0.25 mm), film thickness $1.0 \mu \mathrm{m}$. The oven temperature was held at $50^{\circ} \mathrm{C}$ for $5 \mathrm{~min}$ holding time and raised from 50 to $250^{\circ} \mathrm{C}$ at a rate of $2^{\circ} \mathrm{C} / \mathrm{min}$, employing helium gas $(99.99 \%)$ as a carrier gas at a constant flow rate of $22 \mathrm{~cm} / \mathrm{s}$. 1.0 micron of extract (1 $\mathrm{mg}$ dissolved in $1 \mathrm{ml}$ absolute alcohol), at a split ratio of 1:30 was injected.MS analysis was carried out on Agilent. Technology network Mass spectrometer (model 5973 series) coupled to a Hewlett Packard Gas chromatography Model 6890 series) equipped with NIST08 Library software database. Mass spectra were taken at $70 \mathrm{ev} / 200^{\circ} \mathrm{C}$ scanning rate of $1 \mathrm{scan} / \mathrm{s}$.

\section{Identification of compounds}

Interpretation of mass spectrum of the unknown component was conducted by comparing the mass spectra with the spectrum of the known components stored in the data system National Institute Standard and Technique library (NIST2008, Turbo mass Ver. 5.4.2). The relative percentage amount of each component was calculated by comparing its average peak area to the total areas. The name, molecular weight, structure and mass fragmentation of the components of the test materials were given.

\section{HPLC analysis method}

$10 \mathrm{mg}$ of standard diosgenin was weighed and dissolved in 5 $\mathrm{ml}$ of methanol by means of sonicated for $15 \mathrm{~min}$. The solution was diluted up to $10 \mathrm{ml}$ with methanol $(1 \mathrm{mg} / \mathrm{ml}) .1$ $\mathrm{ml}$ solution was taken out from stock solution and diluted up to $10 \mathrm{ml}$ with methanol $(100 \mu \mathrm{g} / \mathrm{ml})$. The ethinylestradiol and saponin were extracted effectively by alkaline hydrolysis followed by HPLC-UV determination.

The details of the instrument used were Shimadzu Prominence HPLC modular system, Binary Gradient with PDA detector with Shim-pack solar 18C column (Chromolith Chromatography, A Japan Company). It was a reverse phase (stationary phase was non-polar and mobile phase was polar). The column temperature was $40^{\circ} \mathrm{C}$ maintained for all samples. The mobile phases were composed of acetonitrile and water in the proportion of 90:10. The adjustable experimental variables were the conditions of gradient modes and mobile phase compositions. The flowrate was kept at $1 \mathrm{ml} /$ minute. The injection volume was $25 \mu \mathrm{l}$. Ethinylestradiol was detected using absorbance at PDA multilevel $225 \mathrm{~nm}, 4 \mathrm{~nm}$, while diosgenin and saponins were detected using absorbance at 


\section{Indo Global Journal of Pharmaceutical Sciences, 2019; 9(2): 63-68}

PDA multilevel $203 \mathrm{~nm}, 4 \mathrm{~nm}$. Optimization of HPLC conditions as a standard procedure was carried out prior to analysis.

\section{RESULTS AND DISCUSSION}

The selected plants for the study were used by the ethnic and tribal people as traditional contraceptives in Ahmednagar District [12]. So these plants were analyzed to find out the novel phytochemical which may be responsible and correlate with contraception. Phytochemical were screened by GC- MS and HPLC technique. The results are represented in Tables, Graphs and Figures.

\section{Major phytochemical of contraceptive plants:}

The major compounds found in traditional contraceptive plants were further analyzed by HPLC technique (Ethinylestradiol and Diosgenin) and GC-MS technique (Pregnane). High pressure liquid chromatography (HPLC) has been found to be an efficient and sensitive method for identification and quantification of different classes of Ethinylestradiol, Diosgenin and Saponins along with standards. The proposed method is found to be a rapid, efficient method which requires a simple sample preparation for the quantification of phytoestrogens. It was reported that these compounds are directly involved in contraceptive [13, 14, and 15]. The present research investigated the properties of Ethinylestradiol, Diosgenin and Saponins in Moringa oleifera Lam., Trigonella foenum-graecum L. and Sapindus emarginatus Vahl., respectively. HPLC studies showed that the peaks of phytoestrogens obtained from plant extracts were similar with the peaks obtained by standards.

\section{Pregnane- Progesteron by GC-MS:}

Pregnane is a $\mathrm{C}_{21}$ steroid and indirectly a parent of progesterone. The progestogens are one of the five major classes of steroid hormones. All endogenous progestogens are characterized by their basic 21-carbon skeleton, called a pregnane skeleton (C21). Progesterone is an endogenous steroid and progestogen sex hormone involved in the menstrual cycle, pregnancy and embryogenesis of humans and other species [16]. The progestogens are named for their function in maintaining pregnancy, although they are also present at other phases of the estrous and menstrual cycles [17, 18]. Progesterone affects the vaginal epithelium and cervical mucus, making it thick and impenetrable to sperm. Progesterone is anti-mitogenic in endometrial epithelial cells and as such mitigates the tropic effects of estrogen [4]. There is coordination amongst Pregnane, corpora lutea and progesterone. It was reported that homogenates obtained from bovine corpora luteal tissue were found to catalyse the synthesis of 3 beta-hydroxy- 5 alpha- pregnan-20-one (allopregnanolone) from progesterone but not from pregnenolone [19]. The major metabolites of progesterone included allopregnanolone, 5 alpha-pregnane3,20-dione and fatty acid esters of allopregnanolone. Progestogens have actions in the midbrain ventral tegmental area to mediate motivated behaviours such as those involved in reproductive processes and matingamong female rodents. In VTA the formation and actions of one progestogen, $5 \alpha-$ pregnan-3 $\alpha$-ol-20-one $(3 \alpha, 5 \alpha-$ THP)is necessary and sufficient to facilitate sexual responding of female rodents [20]. The roles of progesterone and other progestogens (referring here to progesterone and its neuroactive products including $5 \alpha$-pregnan-3 $\alpha$-ol-20-one; $3 \alpha, 5 \alpha$-THP) beyond their pro-gestational effects are of interest.

\section{Ethinylestradiol by HPLC}

Ethinylestradiol is an estrogen that is active when taken by mouth and is used in almost all formulation of combined birth control pills and is nearly the exclusive estrogen used for this purpose. Estrogen contributes to ovulation suppression [21]. High-performance liquid chromatography (HPLC) analysis was developed and validated for the determination of the contents of Ethinylestradiol compounds in Moringa oleifera Lam. seeds. Analysis of Ethinylestradiol derivatives extracted in petroleum ether and aqueous seed extracts of Moringa oleifera Lam. revealed significantly high levels. Three peaks were elucidated in the chromatogram developed in petroleum ether extract. The highest peak area was obtained by the peak having retention time 3.092 minute with $82.43 \%$ peak area. Second higher peak was obtained at retention time 6.206 minutes which has covered $11.20 \%$ peak area. It was observed that the third peak of the Moringa sample has showed about same retention time 6.206 minutes for Ethinylestradiol with less peak area $11.20 \%$. Simultaneously, the standard Ethinylestradiol peak area and retention time was compared with the Sample peak. The peak obtained in standard was at retention time 6.161 minute with $62.77 \%$ peak area. The spectra 6.206 obtained in petroleum ether extract of Moringa indicate that Ethinylestradiol may be present in more amounts and may be associated with its derivatives. So retention time of standard and observed spectra of sample may be different on chromatogram. The peaks obtained in aqueous extract were totally different with respect to petroleum ether extract due to the concentration.

In Moringa oleifera Lam. the calculated value of ethinylestradiol in petroleum extract was $108.199 \mu \mathrm{g} / \mathrm{ml}$ and655.26 $\mu \mathrm{g} / \mathrm{ml}$ in aqueous extract. As the concentration of the samples increased the peak area was also increased. Hence the above values for the amount of ethinylestradiol in petroleum ether and aqueous extract are variable. From these 
Indo Global Journal of Pharmaceutical Sciences, 2019; 9(2): 63-68

results it was confirmed that Moringa oleifera Lam. contains ethinylestradiol. It is a steroidal estrogen and a derivative of estradiol [22]. It is very essential to evaluate observed (Retention Time $6.206 \mathrm{~min}$ ) compound by more sensitive technique for characterization and quantification of Ethinylestradiol. It has high estrogenic potency when administered orally, and is often used as the estrogenic component in oral contraceptive.

\section{Diosgenin by HPLC}

Diosgenin is a major bioactive constituent of some of the plants. It is the most widely used precursor in the preparation of many steroid drugs, sex hormones and oral contraceptives pills [23, 24]. Presence of diosgenin was reported in Helicteres isora L. [25], Dioscoria [26, 27], Trigonella foenum-graecum L. [28]. It was reported thatTrigonella foenum-graecum L. seeds contain considerable amount phytoestrogens such as isoflavones, lignans and coumestrol [29]. In the present study the concentration of Diosgenin was estimated in the seeds of Trigonella foenum- graecum L. by using HPLC technique.

The concentrations of diosgenin in aqueous and petroleum ether extract of Trigonella foenum-graecum L. were calculated by measuring the peak area of samples comparing with peak area of standard diosgenin. In petroleum ether extract of Trigonella foenum-graecum L. multiple peaks of compounds were obtained but one of them was having major contribution with higher peak area. It was 6762643 peak areas at 3.131 retention time. At this peak concentration of diosgenin was $1.280 \mathrm{mg} / \mathrm{ml}$. In the aqueous extract also various peaks were obtained. Two of them were major with higher peak areas. The first peak was with retention time 2.779 and the area was 26667760 while second peak was with retention time 2.893 and the area was 13150414 . These areas were calculated and compared with the peak area of standard. The concentration of diosgenin in aqueous extract was $5.098 \mathrm{mg} / \mathrm{ml}$ in the first peak with retention time 2.779 while it was $2.506 \mathrm{mg} / \mathrm{ml}$ in the second peak with retention time 2.893. The present HPLC analysis showed that Trigonella foenum-graecum L.contains measurable amount of diosgenin. In the present study the highest diosgenin levels were observed in seeds of $T$. foenumgraecum $\mathrm{L}$. which was in agreement and comparable with the report $[28,30,31]$.

Figure 1 GC MS Profile of T. foenum-graecum seeds showing Pregnane

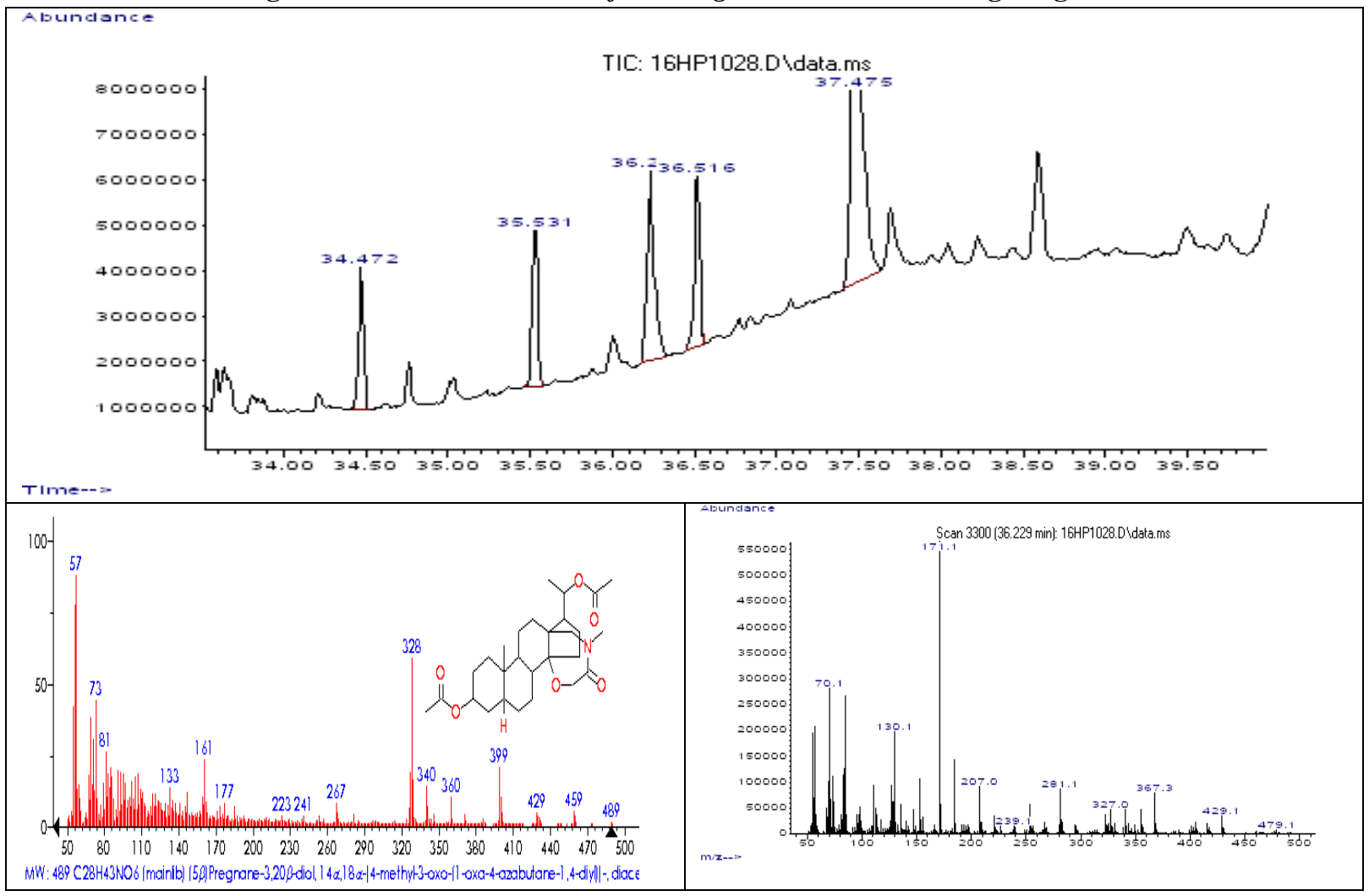


Indo Global Journal of Pharmaceutical Sciences, 2019; 9(2): 63-68

Figure 2: HPLC Chromatoram of Ethynylestradiol standard and extracts of Moringa oleifera Lam.

$<$ Chromatogram>

MAU

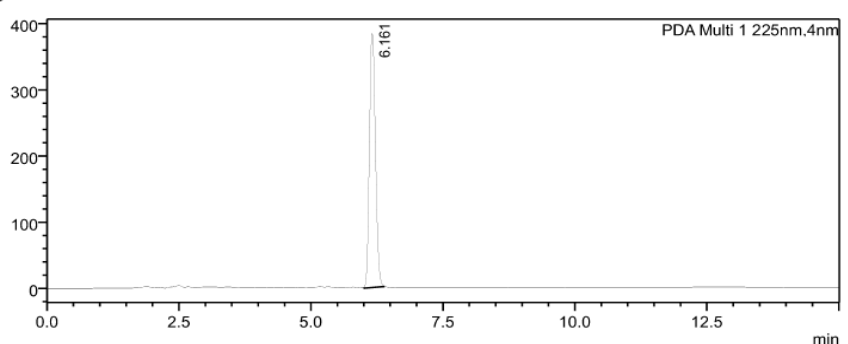

Chromatogram of Ethynylestradiol std

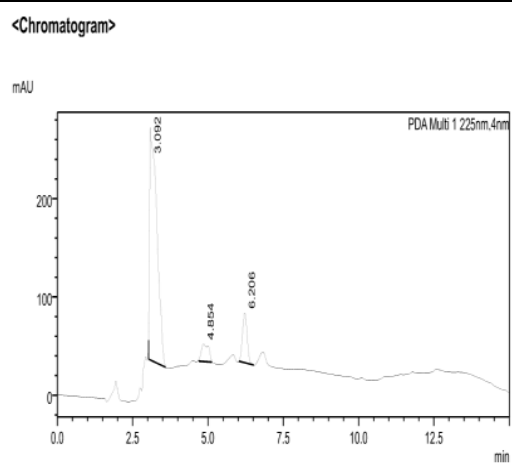

Chromatogram in pet ether extract of Moringa seeds.
〈Chromatogram》

MAU

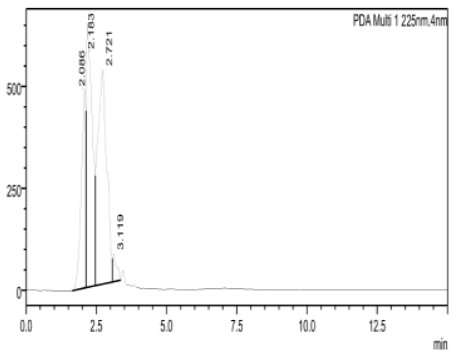

Chromatogram in aqueous extract of Moringa seeds

Figure 3: HPLC Chromatogram of standard Diosgenin and extract of Trigonella seeds

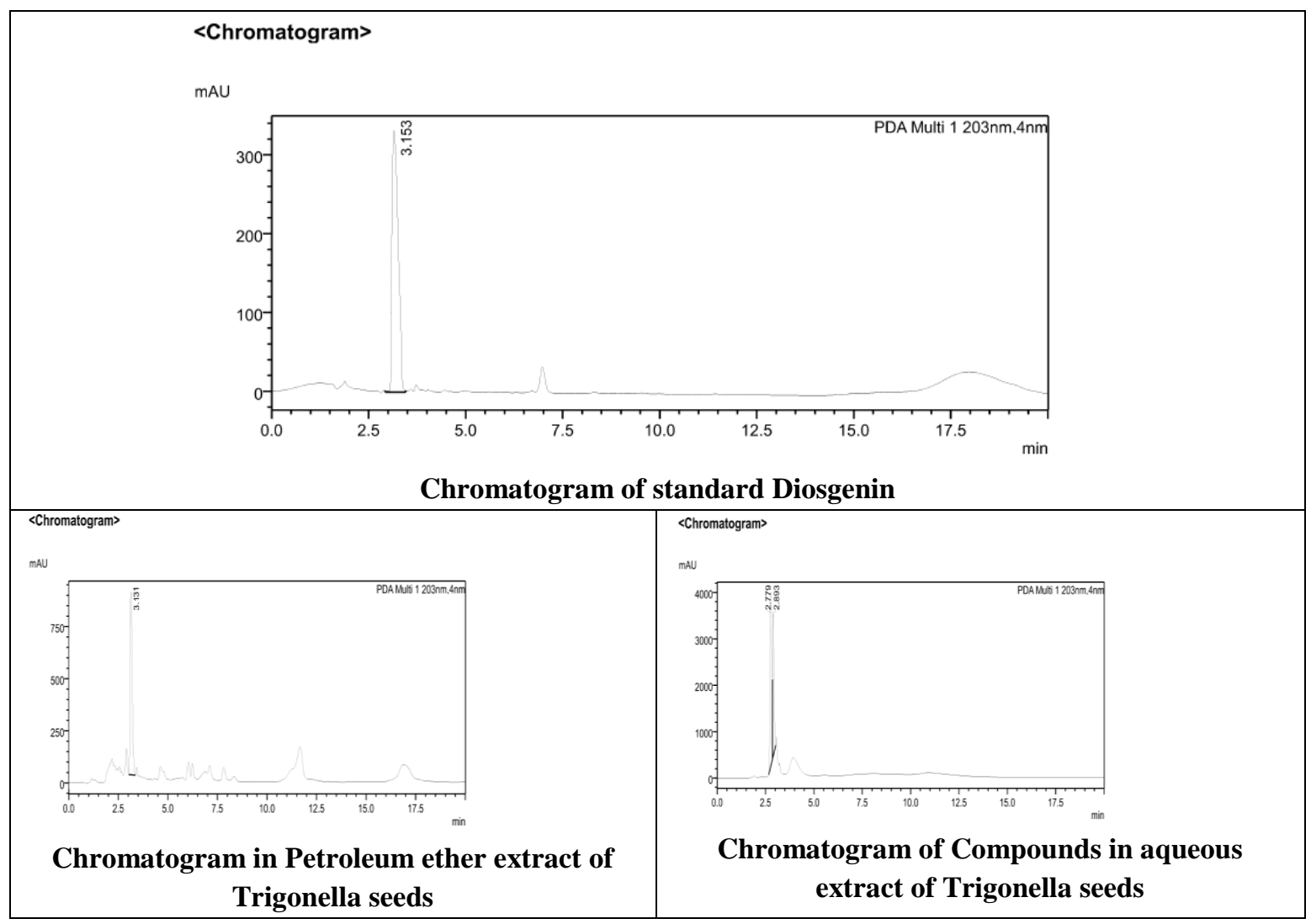




\section{Indo Global Journal of Pharmaceutical Sciences, 2019; 9(2): 63-68}

\section{CONCLUSION}

Pregnane, Ethynylestradiol and Diosgenin are the phytochemicals which showing antifertility activity. In future, these may be used for preparation of molecular condom. It may be used for developing a non-hormonal form of contraception that could be used after sex to prevent sperm from reaching their goal. This molecular condom could be useful for those who are opposed to using existing options. There is also the possibility that the molecular condom which is channel blockers could work their magic from the man's side before they set off on their journey delivered through a pill or patch.

\section{REFERENCES}

[1] Vinoth, B., Manivasagaperumal, R., Balamurugan, S. Phytochemical analysis and antibacterial activity of Moringa oleifera Lam. International Journal of Research in Biological Sciences, 2012; 2(3): 98-102.

[2] Abdulkadir, I. S., Nasir, I. A., Nasir, A. Phytochemical Screening and Antimicrobial Activities of Ethanolic Extracts of Moringa oleifera Lam. on Isolates of Some Pathogens. J App. Pharm., 2015; 7 (4): 203.

[3] Arora, B., Bhadauria, P., Tripathi, D., Sharma A. "Sapindus Emarginatus: Phytochemistry \& Various Biological Activities" Indo Global Journal of Pharmaceutical Sciences, 2012; 2(3): 250-257.

[4] Patel, P., Patel, N., Patel, D., Deasi, S., Meshram, D. Phytochemical analysis and Antifungal activity of Moringa oleifera. International Journal of Pharmacy and Pharmaceutical Sciences, 2014; 6 (5): 257-260.

[5] Suhagia, B.N., Rathod I.S., Sindhu S. Sapindus mukorossi (Areetha): An Overview. IJPSR, 2011; 2(8): 1905-1913.

[6] Foye, W.O., Lemke T.L., Williams D.A. Foye's Principles of Medicinal Chemistry. 6th Ed Lippincott Williams and Wilkins. Philadelphiap., 2008; 44-45.

[7] Gordon M.C., David J.N. Natural product drug discovery in the next millennium. Pharm. Biol. 39 Suppl., 2011: 8-17.

[8] Cowan M.M. Plant products as antimicrobial agents, Clin. Microbiol. Rev., 1999; 14: 564-584.

[9] Farnsworth N.R., Akerele O., Bingel A.S., Soejarto D.D., Guo, Z. Medicinal plants in therapy. Bull. WHO, 1985; 63: 965-981.

[10] Gaykar B.M., Kulkarni A. A, and G.B Borkar. (2006). Ethnobotanical plants of tribal areas of Ahmednagar Dist. (M.S) Jour. Drug Res. Aurveda and Sidhha" vol XXVII No 1-2 pp 73-61.

[11] Mawahib E. M., Nour E. I., Ammar M. A., Ali B. E., Saeed A. E. Antimicrobial Activities and Phytochemical Screening of Callus and Seeds Extracts of Fenugreek (Trigonella fenum-graecum) Int. J. Curr. Microbiol. App. Sci., 2015; 4(2): 147-157.
[12] Kadam A. B., Gaykar B.M., Bedarkar P. Systematic study on understanding present and prospective contraceptives. Flora and Fauna, 2013; 19(1):51-57.

[13] Nathalie K. WHO provider brief on hormonal contraception and liver disease. Contraception, 2009; 80: 325-326.

[14] Patel K., Gadewar M., Tahilyani V., Patel D. A review on pharmacological and analytical aspects of diosgenin: a concise report Nat. Prod. Bioprospect, 2012; 2: 46-52.

[15] Zongliang Z., Wang L., Zhou R., Qiu Y., Yang L., Zhang C., et al. Evaluation of the Spermicidal and Contraceptive Activity of Platycodin D, a Saponin from Platycodon grandiflorum. PLoS ONE, 2013; 8(11): e82068.

[16] King TL and Brucker MC. Pharmacology for Women's Health. Jones \& Bartlett Publishers 2010; 372-373.

[17] Clark MA, Richard A, Harvey, Richard F, Jose A, Rey, and Karen W: Pharmacology. Lippincott Williams \& Wilkins 2011; 322.

[18] Bhattacharya: Pharmacology Elsevier India. 2003; 378.

[19] Albert DH, Prasad VV, Lieberman S: The conversion of progesterone into 5 alpha-pregnane-3,20-dione, 3 beta-hydroxy- 5 alpha-pregnan-20-one, and its fatty acid esters by preparations of bovine corpora lutea. Endocrinology 1982; 111(1): 17-23.

[20] Frye C, Koonce AC and Walf AA: Pregnane Xenobiotic Receptors and Membrane Progestin Receptors: Role in Neurosteroid-Mediated Motivated Behaviours Journal of Endocrinology 2013; 25(11):1002-1011.

[21] Evans G., Sutton E. L. Oral contraception. Med Clin North Am., 2015; 99(3): 479-503.

[22] Elks J. The Dictionary of Drugs: Chemical Data: Chemical Data, Structures and Bibliographies.Springer. 2014; pp 522.

[23] Puri, S., Jefferies, M. and Harh, R. (). Diosgenin and yamogenin levels in some Indian plant samples. Planta Med 1976; 30: 118-121.

[24] Kumar V., Desai D., Shriram V. Hairy Root Induction in Helicteres isora L. and Production of Diosgenin in Hairy Roots. Nat. Prod. Bioprospect. 2014; 4:107-112.

[25] Deshpande H. A., Bhalsing S. R. Isolation and characterization of diosgenin from in vitro cultured tissues of Helicteres isora L. Physiol Mol Biol Plants, 2014; 20 (1): 89-94.

[26] Yi et al. Comparative analysis of Diosgenin in Dioscoria species and related medicinal plantsby UPLC-DAD-MS. BMC Biochemistry, 2014; 15:1

[27] Shah H. J., Lele S. S. Extraction of Diosgenin, a Bioactive Compound from Natural Source Dioscorea alata Var purpurae Techniques J Anal Bioanal Techniques, 2012; 3(4):141-143.

[28] Taylor WG, Elder JL, Chang PR, \& Richards KW. Microdetermination of diosgenin from fenugreek (Trigonella foenum-graecum) seeds. J Agric Food Chem. 2000; 48: 5206-5210.

[29] Joshi M., Nair S. HPLC analysis of Trigonella foenum-graecum seeds to assess phytoestrogens. International Journal of food and Nutritional Science, 2014; (3)1.

[30] Trivedi, P. A validated quantitative thin layer chromatography method for the estimation of diosgenin in various plant samples, extract and market formulations. J. AOAC Int., 2007; 90: 358-363.

[31] Dangi R. Misar A. Tamhankar S. Rao S. Diosgenin content in some Trigonella species. Indian J. Adv. Plant Res. 2104; 1(2): 47-51.

Indo Global Journal of Pharmaceutical Sciences( ISSN 2249 1023; CODEN- IGJPAI; NLM ID: 101610675) indexed and abstracted in CrossRef (DOI Enabling), UGC CARE Journal List, EMBASE(Elsevier), National Library of Medicine (NLM) Catalog, ResearchGate, Publons, CAS (ACS), Index Copernicus, Google Scholar and many more. For further details, visit http://iglobaljournal.com

This is a special issue as an outcome of 'International Conference on Recent Advances in Traditional Medicine, Medicinal Plants and Phytochemistry' jointly organized by Ahmednagar College, India and AIMST University, Malaysia. Relaxation offered in journal format. 